удк 378.81:37.014.6:6

Олена Семеног

Сумський державний педагогічний університет імені А. С. Макаренка ORCID ID 0000-0002-8697-8602

Маргарита Надутенко Український мовно-інформаційний фонд НАН України ORCID ID 0000-0003-3215-0970

Тимошук Роман Інститут славістики Польської академії наук, Польща ORCID ID 0000-0003-1391-164X DOI 10.24139/2312-5993/2020.10/245-258

\title{
НАЦІОНАЛЬНІ ЛІНГВІСТИЧНІ РЕСУРСИ УКРАЇНСЬКОГО МОВНО- ІНФОРМАЦІЙНОГО ФОНДУ НАН УКРАЇНИ - ЕФЕКТИВНИЙ ЗАСІБ ФОРМУВАННЯ АКАДЕМІЧНОЇ КУЛЬТУРИ ДОСЛІДНИКА
}

У статті здійснено огляд національних лінгвістичних ресурсів Українського мовно-інформаційного фонду НАН України як ефрективного засобу в підготовці майбутніх учителів-словесників до формування академічної культури (термінологічної, лексикографрічної) учня-дослідника. Доведено, що електронні національні лінгвістичні ресурси характеризуються гнучкістю, оперативністю обробки інформації, модульністю побудови, сприяють оновленню й оптимізації навчально-пізнавальної діяльності за максимально короткий проміжок часу. Висвітлено окремі результати міждисциплінарного проєкту Загальноукраїнського центру словникарства Українського мовно-інформаційного фонду НАН України та кафедри української мови і літератури Сумського державного педагогічного університету імені А. С. Макаренка.

Ключові слова: академічна культура, дослідник, цифрові ресурси, електронний словник, національна словникова база, Загальноукраїнський центр словникарства Українського мовно-інформаційного фонду НАН України, кафедра української мови і літератури, міждисциплінарний проєкт.

Постановка проблеми. Концепт «якість освіти» усе більшою мірою знаходить відображення в українських законодавчих документах і наукових публікаціях. Загалом ідеться про відповідність результатів навчання вимогам, установлених законодавством, про відповідність стандарту освіти, про певний рівень знань і вмінь, розумового, фізичного й морального розвитку, якого досягають випускники освітнього закладу відповідно до запланованих цілей навчання і виховання (Методичні рекомендації щодо розроблення стандартів вищої освіти).

Якісні результати навчання значною мірою досягаються культурою навчання, дослідницької роботи, тобто академічною культурою, академічною грамотністю учасників освітнього процесу. Поняття академічна культура, як показує аналіз і узагальнення наукових джерел, уживають на позначення інституційної культури, цінності університету/закладу освіти, культури навчання, соціальної, моральної відповідальності за результати дослідження; 
академічної/читацької

грамотності

студентів

(учнів)

Ta вчителів/викладачів/наукових наставників (Семеног та Вовк, 2016).

Водночас, аналіз дослідження Міжнародної програми з оцінювання освітніх досягнень учнів PISA у 2018 році засвідчує, що за показником, наприклад, здатності сприймати, аналізувати, використовувати й оцінювати письмовий текст задля досягнення певних цілей, розширювати свої знання й читацький потенціал здобувачі освіти віком до п'ятнадцяти років набрали загалом лише 466 балів із 1000 можливих (Schleicher, 2019).

На формування читацької компетентності учнів/студентів значною мірою впливає сформованість словникової культури як важливий індикатор академічної культури. На заняттях, у позакласній роботі $\epsilon$ необхідність формування у старшокласників/студентів потреби, здібностей, умінь виконувати пізнавальні, комунікативні, проблемнопошукові завдання, користуючись різноманітними словниками.

Створення лексикографічного портрета слова чи групи слів потребує одночасного звернення до словників різних типів, у т.ч. до електронних словників. Вагоме місце відводимо сучасним електронним лінгвістичним ресурсам.

Поняття електронні освітні ресурси розглядаємо відповідно до Положення про використання електронних освітніх ресурсів (2012) як навчальні, наукові, інформаційні, довідкові матеріали й засоби, що розроблені в електронній формі та представлені на носіях будь-якого типу або розміщені в комп'ютерних мережах, відтворюються за допомогою електронних цифрових технічних засобів і використовуються для забезпечення навчальної діяльності здобувачів (Про використання електронних освітніх ресурсів, 2012).

До потужних електронних лінгвістичних ресурсів відносять національні лінгвістичні ресурси Українського мовно-інформаційного фонду НАН України. Національна словникова база України охоплює, зокрема граматичний словник (зі змінами відповідно до Нової редакції Українського правопису (див. https://www.ulif.org.ua/system/files/pravopus-new.pdf), тлумачний словник української мови, інші словники й цифрові лінгвістичні системи, які подають семантичний, прагматичний, статистичний, лінгвогеографічний опис української мови та інших основних мов світу, а також Український національний лінгвістичний корпус, цифрову систему національної термінології та термінографії, національну цифрову енциклопедичну базу тощо.

Використання сучасних лінгвістичних технологій в освітньому процесі забезпечує користувачам максимально швидкий самостійний пошук 
необхідної інформації, дозволяє визначити чи конкретизувати сутність поняття, оцінити лексеми щодо нормативності уживання, відповідності сфері й ситуації спілкування, уникати типових мовних помилок і сприяє формуванню академічної культури здобувачів освіти.

Перспективним напрямом, що сприяє формуванню академічної культури дослідника засобами електронних словників, вважаємо міждисциплінарні проєкти: кафедра університету - Український мовно-інформаційний фонд НАН України - старша школа. Зокрема, відповідно до угоди про науковометодичну співпрацю, кафедра української мови і літератури Сумського державного педагогічного університету імені А. С. Макаренка та Загальноукраїнський центр словникарства Українського мовно-інформаційного фонду НАН України ініціювали спільний проєкт «Словникова культура дослідника», спрямований на формування, зокрема, термінологічної, лексикографічної культури дослідника засобами електронних словників.

Аналіз актуальних досліджень. Сутність, основні вимоги щодо дотримання академічної культури, доброчесності у процесах викладання та навчання концептуалізовано в міжнародних документах (Всесвітній економічний форум у Давосі (2016), Рамкова програма оновлених ключових компетентностей для навчання протягом життя (2018)), у Законі України «Про освіту» (2017), «Про забезпечення функціонування української мови як державної» (2019), у Концепції «Нова українська школа» (2016)). Питання академічної культури студента досліджує І. Пак, проблеми академічної комунікації та академічної грамотності - Ж. Колоїз, І. Шліхта, Н. Шліхта. У публікаціях авторів статті здійснено розгляд специфіки концепту «академічна культура дослідника» в українському і польському освітньо-педагогічному дискурсах (Семеног, 2020) як вагомий складник національної інноваційної безпеки (Semenog, 2020).

Організація навчально-дослідницької роботи школярів із використанням українського національного лінгвістичного корпусу; Національні лінгвістичні ресурси УМІФ, загальний огляд та перспективи використання національних лінгвістичних цифрових ресурсів Українського мовноінформаційного фонду НАН України - ці питання досліджують В. Широков, О. Стрижак, І. Олександрук, Максим і Маргарита Надутенки (Широков та ін., 2018; Довгий та ін., 2013; Надутенко, 2020; Гальченко та ін., 2013).

Мета статті. У межах статті здійснимо огляд національних лінгвістичних ресурсів Українського мовно-інформаційного фонду НАН України як ефективного засобу у формуванні академічної культури 
дослідника в межах міждисциплінарного проєкту: кафедра університету Український мовно-інформаційний фонд НАН України - старша школа.

Методи дослідження: аналіз наукових джерел; вивчення національних лінгвістичних ресурсів УМІФ НАН України, аналіз досвіду співпраці науково-дослідної лабораторії «Академічна культура дослідника» кафедри української мови i літератури Сумського державного педагогічного університету імені А. С. Макаренка та Загальноукраїнського центру словникарства Українського мовно-інформаційного фонду НАН України; розробка й упровадження в освітню діяльність національних лінгвістичних ресурсів УМІФ НАН України.

Виклад основного матеріалу. Проведений аналіз навчальних дисциплін для магістрантів та аспірантів Сумського державного педагогічного університету імені А.С. Макаренка «Академічна культура педагогадослідника», «Методика навчання української мови у старшій школі» засвідчує наявність модулів і тем 3 академічної доброчесності, термінологічної, словникової культури дослідника. Мета модулів і тем сприяти формуванню здатності навчатись і самонавчатись: знаходити, обробляти й аналізувати інформацію з різних джерел, у т.ч. використовуючи інформаційні, комп'ютерні та комунікаційні технології, лінгвістичні навички.

Упродовж занять, у самоосвітній та дослідницькій діяльності пропонуємо студентам, аспірантам використовувати здобутки корпусної лінгвістики.

Прикметною рисою XXI століття $€$ інтенсивний розвиток корпусної лінгвістики, яка опікується вивченням фактів, текстів мови на основі використання комп'ютера для аналізу, збереження й опрацювання лексикографічної інформації (Широков, 2003). Корпусна лінгвістика та лексикографія дають змогу постійно збільшувати кількість лексичних одиниць, не очікуючи чергового перевидання словника, що значно економить час і матеріальні ресурси.

Комп'ютерної лексикографії стосуються й основні наукові здобутки УМІФ НАН України, що функціонує з 1991 р. (директор - лауреат Державної премії України в галузі науки і техніки академік НАН України В. Широков). Український мовно-інформаційний фонд $\epsilon$ базовою організацією Національної словникової бази України, яку за рішенням уряду України внесено до Державного реєстру наукових об єктів як національне надбання України (розпорядження Кабінету Міністрів України від 11.02.2004 р. № 73-р). Основна частина електронних ресурсів Українського мовно-інформаційного фонду знаходиться у вільному доступі й може бути використана в освітній 
діяльності (див. ресурси на сайті Українського мовно-інформаційного фонду НАН України - режим доступу http://lcorp.ulif.org.ua/ LSlist/).

Серед видань УМІФ НАН України відзначимо перший український повномасштабний електронний словник на CD, інтегрована лексикографічна система «Словники України» (див. https://lcorp.ulif.org.ua/dictua/), що охоплює словникові модулі словозміни, транскрипції, синонімії, антонімії та фразеології. В УМІФ створено перший в Україні Національний лінгвістичний корпус (понад 200 млн. слововживань), який містить електронну бібліотеку морфологічно анотованих українських текстів та електронний каталог цифрової лексичної картотеки з розвиненими мовно-інформаційними функціями. Національний лінгвістичний корпус слугує експериментальним підґрунтям для проведення фундаментальних мовознавчих досліджень та укладання сучасних лексикографічних праць.

Розроблено й уведено в експлуатацію інформаційно-лінгвістичну систему, що функціонує в Інтернеті, зазначає В. Широков, - Український лінгвістичний портал (www.ulif.org.ua); розроблено концепцію Всеукраїнського лінгвістичного діалогу - мережевої системи професійної взаємодії в лінгвістиці (Широков, 2017).

УМІФ НАН України спільно 3 науково-дослідною лабораторією «Академічна культура дослідника» кафедри української мови і літератури Сумського державного педагогічного університету імені А. С. Макаренка ініційовано міждисциплінарний проєкт: кафедра університету Загальноукраїнський центр словникарства Українського мовноінформаційного фонду НАН України - старша школа. Предметом науковоосвітньої співпраці $€$ формування академічної культури особистості фахівця-дослідника в умовах формальної, неформальної, інформальної освіти; упровадження інноваційних технологій в освітній процес.

На заняттях із мовно-методичних дисциплін ознайомлюємо здобувачів освіти із сайтом Українського мовно-інформаційного фонду НАН України (ulif.org.ua) та його online- ресурсами; формулюємо правила користування електронними словниками. Укладаємо бібліографію електронних словників, користуючись пошуковою системою Інтернету, визначаємо їх тип і функціональне призначення. Аналізуємо переваги електронного словника порівняно з друкованим.

Безперечно, електронні словники надають користувачеві безліч додаткових можливостей порівняно з друкарськими аналогами: дозволяють зберігати великий обсяг інформації завдяки використання гіперпокликань; мають ефективну систему пошуку (повнотекстовий або 
одночасний пошук у кількох словниках, швидкість пошуку); в електронних словниках можуть застосовуватися засоби мультимедіа. $€$ можливість використання словників як в у локальній, так і в глобальній мережах.

За допомогою Електронного тлумачного словника (services.ulif.org.ua/expl/; sum20ua.com) з'ясовуємо значення ланцюжка: дослідження, академічна доброчесність, європейський, новаторство, авторитет. Зокрема, слово дослідження (Рис. 1. - Словник української мови online томи 1-11 (А-Оя́СНЮВАТИ) презентовано у словнику декількома тлумаченнями: «1. Піддавати що-небудь ретельному науковому розгляду з метою пізнання, з'ясування; 2. Ретельно обстежувати кого-, що-небудь, уважно знайомитися з чим-небудь для встановлення чогось; 3. Наукова праця, у якій досліджується яке-небудь питання».

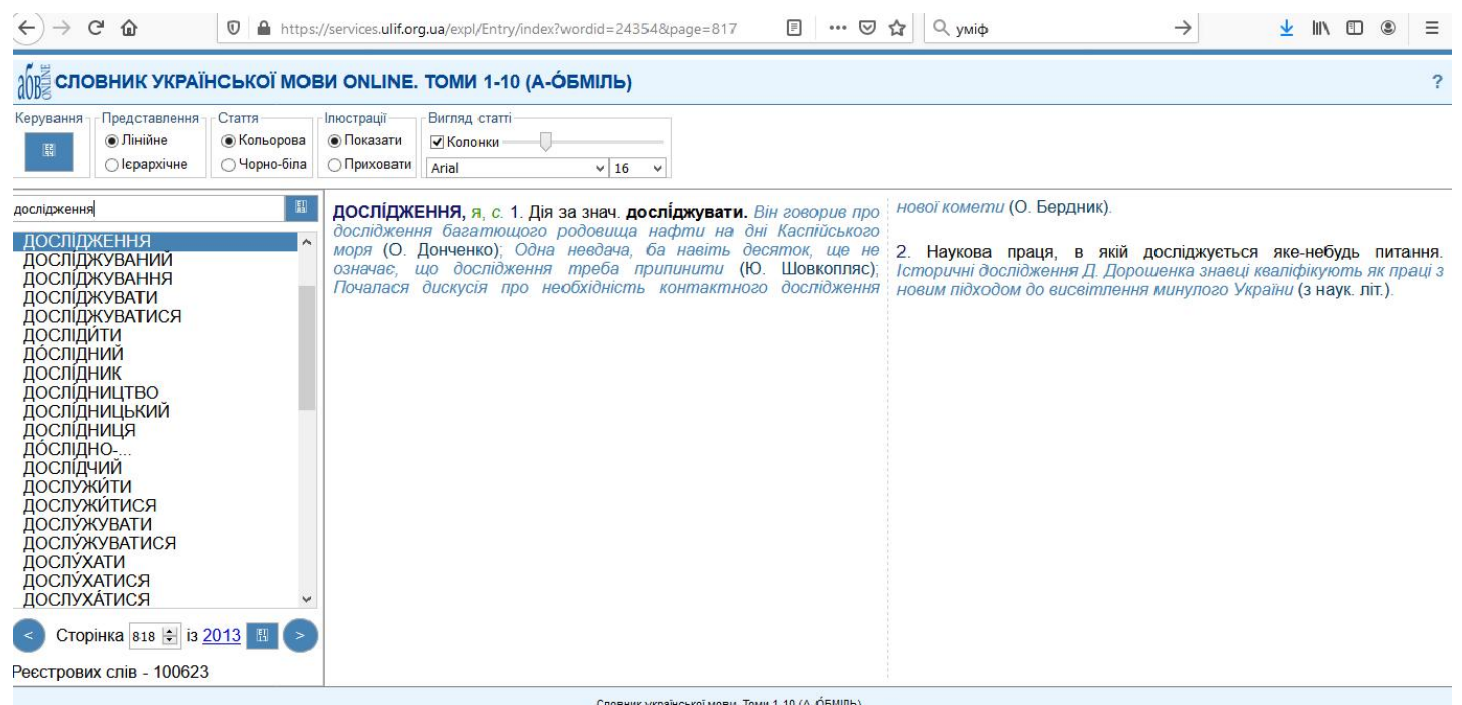

Рис. 1. - Словник української мови online томи 1-11 (А-оя́снЮвАТИ) https://services.ulif.org.ua/expl/Entry/index? wordid=24354\&page=817).

Характеризуємо поняття «академічний» як таке, що стосується освіти, навчання, викладання, досліджень, дотримується традицій, канонів; високохудожній; почесний (Рис. 2. Словник української мови online томи 111

(А-Оя́СНЮВАТИ)

https://services.ulif.org.ua/ expl/Entry/index? wordid=635\&page=27). 


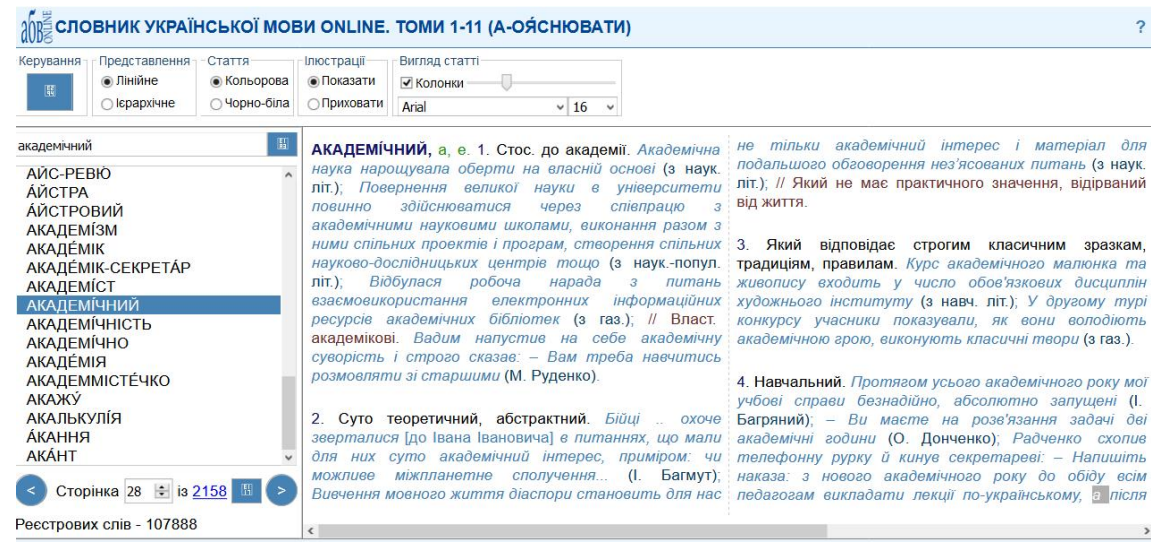

Рис. 2. Словник української мови online томи 1-11 (А-Оя́сНЮВАТИ) https:// services.ulif.org.ua/ expl/Entry/index? wordid=635\&page $=27$

Така робота $є$ основою для подальшого аналізу словосполучення «академічна доброчесність», під час якого оперуємо визначенням статті 42 Закону України «Про освіту» (2017): сукупність етичних принципів та визначених законом правил, якими мають керуватися учасники освітнього процесу під час навчання, викладання та провадження наукової (творчої) діяльності з метою забезпечення довіри до результатів навчання та/або наукових (творчих) досягнень (Про освіту, 2020). Наголошуємо, що згідно з пунктом 3 статті 58 Закону України «Про вищу освіту» (2014) науковопедагогічні, наукові та педагогічні працівники закладу вищої освіти зобов'язані дотримуватися в освітньому процесі та науковій (творчій) діяльності академічної доброчесності та забезпечувати її дотримання здобувачами вищої освіти. Зі свого боку, особи, які навчаються в закладах вищої освіти, зобов'язані виконувати вимоги освітньої (наукової) програми (індивідуального навчального плану (за наявності), дотримуючись академічної доброчесності, та досягати визначених для відповідного рівня вищої освіти результатів навчання (Про вищу освіту, 2020).

На бінарних заняттях з методики навчання української мови спільно зі студентами, М. Надутенко, наук. співр. відділу лінгвістики Українського мовно-інформаційного фонду Національної академії наук України, керівник Загальноукраїнського центру словникарства, аналізує й термін дослідницька доброчесність як ціннісну парадигму Європейського дослідницького простору, зокрема лексеми добро і честь. Зазначаємо, що лексема честь означає сукупність вищих моральних принципів, якими людина керується у своїй поведінці; повага, пошана, визнання кого-, чого-небудь.

До ключових понять дослідника, які фіксують і електронні словники, відносимо лексему компетентний (див. Словник української мови online томи 1-11 (А-Оя́СНЮВАТИ): «1. Який має достатні знання в якій-небудь 
галузі; який із чим-небудь добре обізнаний; 2. Який має певні повноваження; повноправний, повновладний». Водночас розширюємо значення цього поняття характеристикою таких понять, як крос-культурна компетентність (cross cultural competence), грамотність (Literacy competence), мовна, мовленнєва компетентність (Languages competence), компетентність культурної обізнаності та самовираження (Cultural awareness and expression competence) (Семеног, 2019).

3-поміж лексем, актуалізованих у наукових працях, відзначимо лексему європейський (Рис. 3. Словник української мови online томи 1-11 (А-Оя́СНЮвАТИ), яка увиразнилася в сучасному українському суспільстві 3 метою «рівнятися на світові стандарти» і знайшла відображення в низці спільнокореневих слів: європеєць, європейський, по-європейському, європейськість тощо.

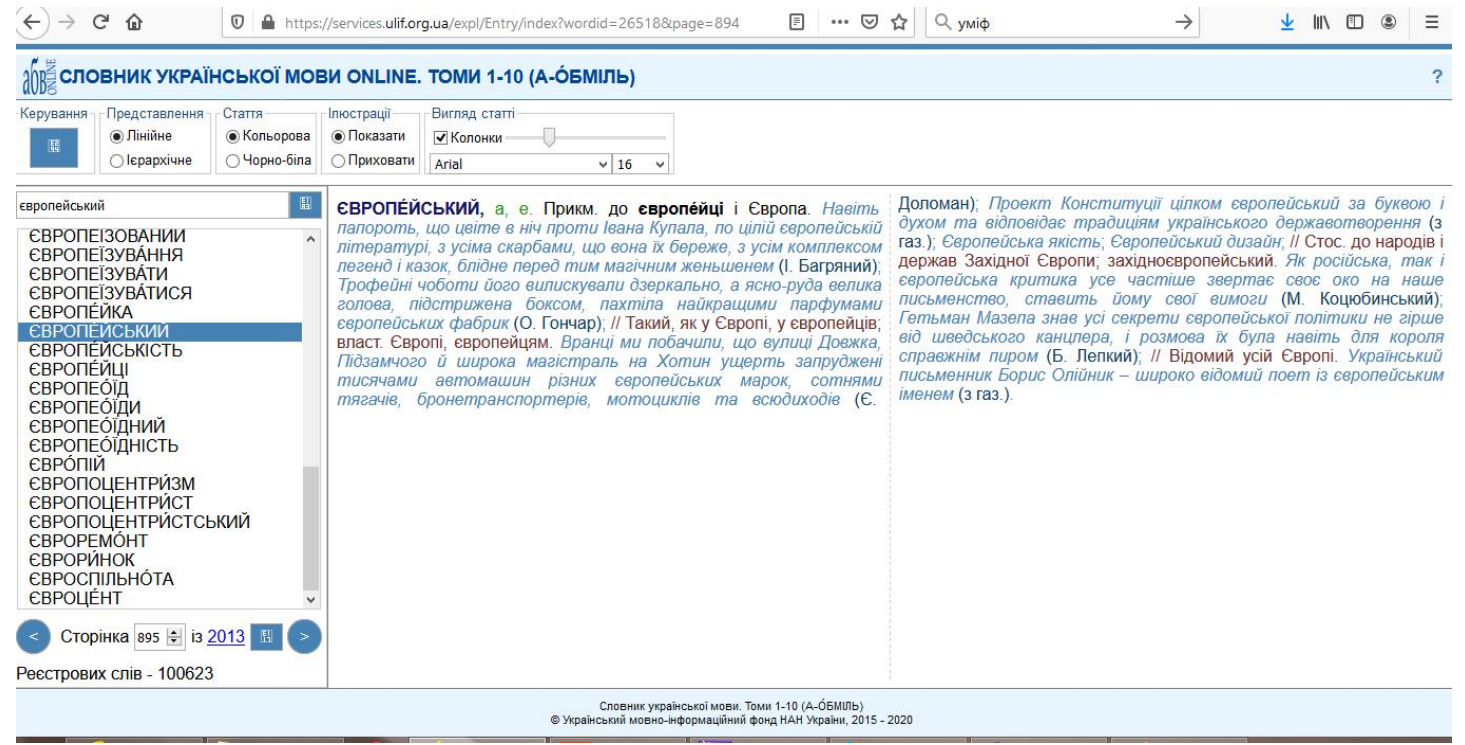

Рис. 3. - Словник української мови online томи 1-11 (А-Оя́снЮвАТИ) https://services.ulif.org.ua/exp//Entry/index? wordid $=26518 \&$ page $=894$

Словник подає значення та відтінки значення: прикм. до європе́йці і Європа. Такий, як у Європі, у європейців; власт. Європі, європейцям; стос. до народів і держав Західної Європи; західноєвропейський; відомий усій Європі.

Точність у вживанні відтінків слова пов'язана з глибоким розумінням лексичного значення, яке найпотрібніше у відповідній ситуації. Пропонуємо ілюстрацію лексичного значення на прикладі слова новаторство (Рис. 4. Словник української мови online томи 1-11 (Аоя́СНЮвАТИ). Аналізуємо такі значення: «Усе нове, прогресивне, що запроваджується в якій-небудь галузі людської»; «Діяльність новатора» на прикладі цитат з різних жанрових категорій. 


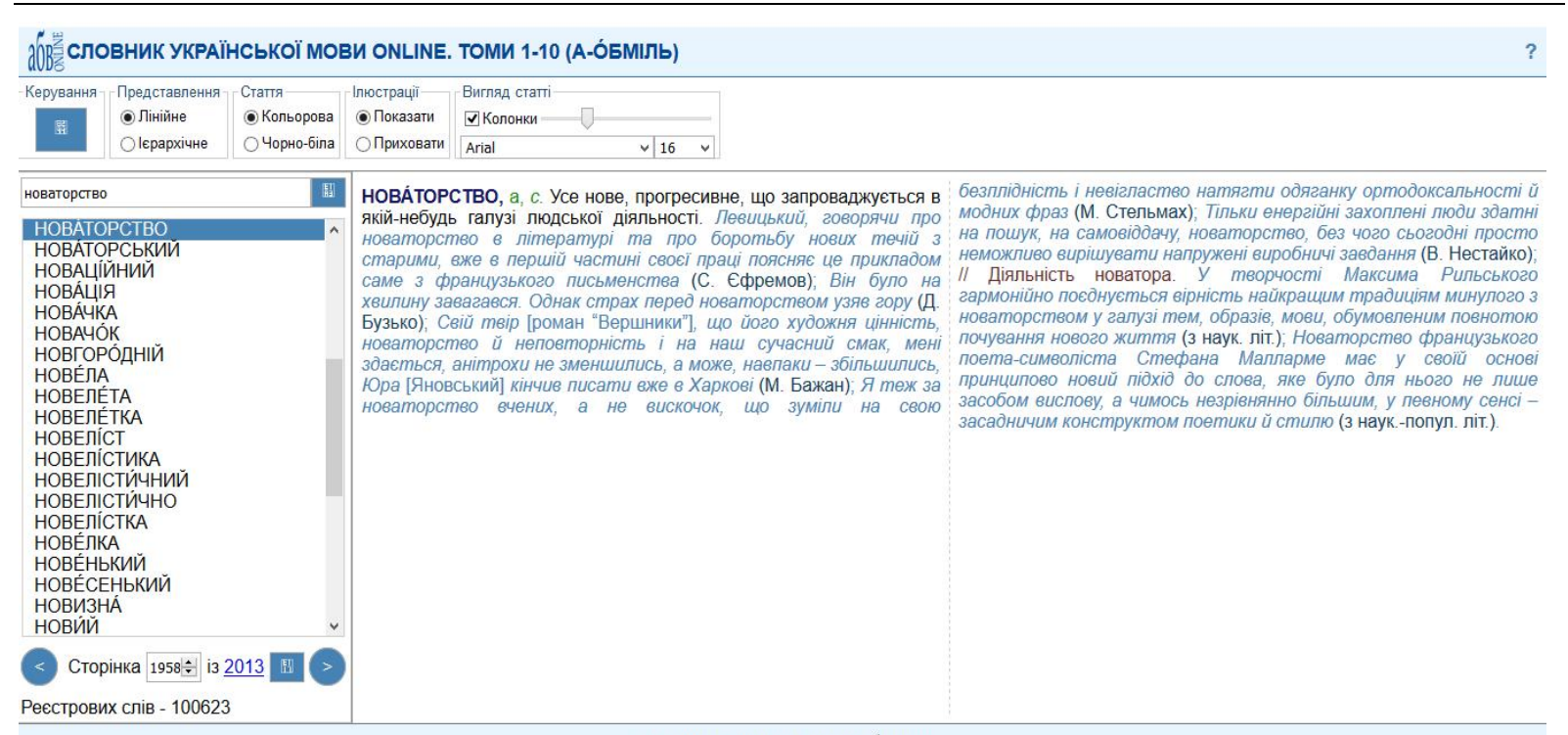

Рис. 4. Словник української мови onliine томи 1-11 (А-Оя́СНЮВАТИ) https:// services.ulif.org.ua/expl/Entry/index? wordid $=61248 \&$ page $=1957$

Аналіз здійснюємо на засадах лінгвопраксеологічного підходу, що ґрунтується на принципах праксеології: якість, успішність, продуктивність, результативність, ефективність.

3 допомогою тлумачного словника (http://services.ulif.org.ua/expl/; http://sum20ua.com.) опрацьовуємо значення слова aвторитет та підбираємо синоніми за допомогою словника (http://lcorp.ulif.org.ua/dictua/). Словник презентує декілька тлумачень залежно від сфери вживання: загальновизнане значення, вплив, поважність (особи, організації, колективу, теорії тощо); авторитет - особа, яка має вплив, повагу, заслуговує на повну довіру; лідер, ватажок кримінального угруповання.

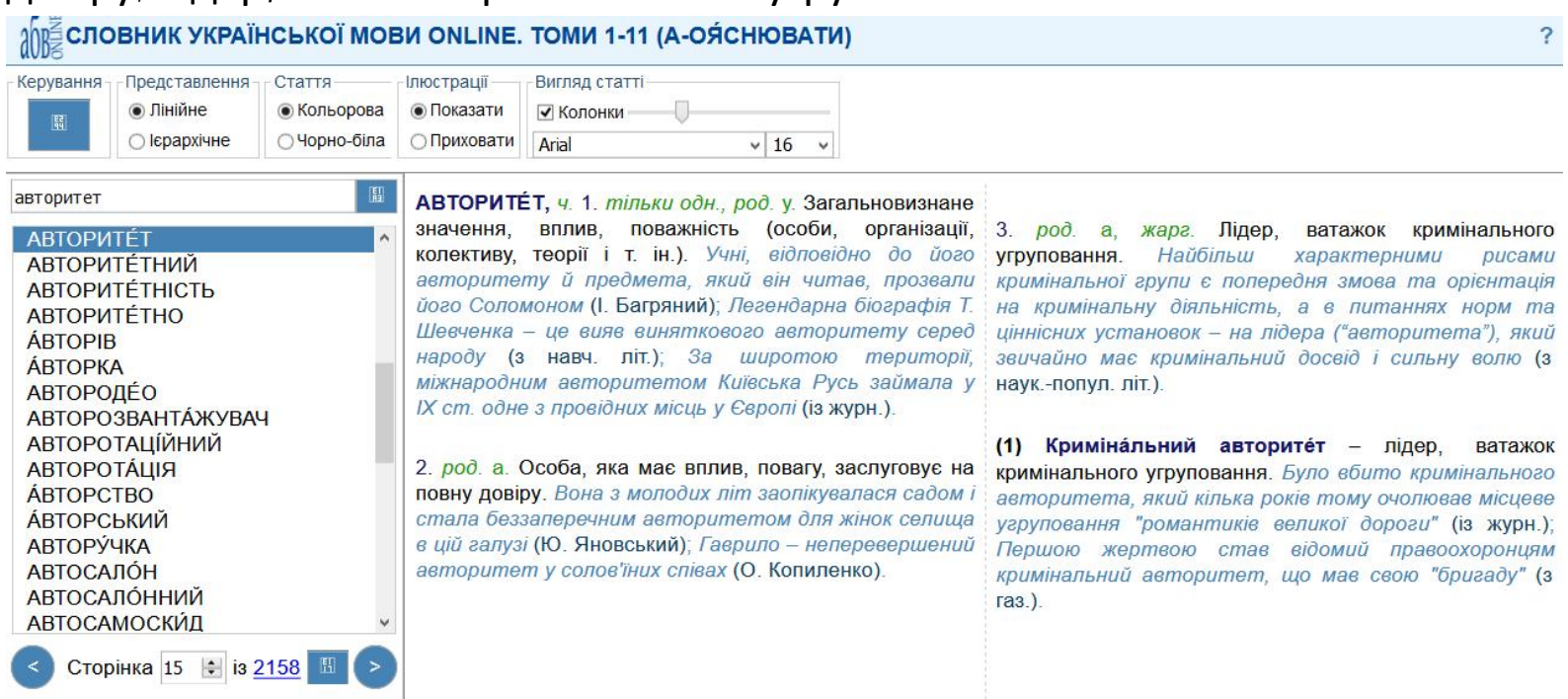

Рис. 5. Словник української мови onliine томи 1-11 (А-Оя́снЮвАТИ) https:// services.ulif.org.ua/expl/Entry/index? wordid=316\&page=14 
Упродовж занять пишемо есе про один із електронних словників, його потребу для дослідника, урахуючи його мету, обсяг інформації на слайді, вікові особливості глядачів, специфіку сприйняття інформації 3 екрана, вплив кольору і шрифту на розуміння інформації. Аналізуємо відмінності призначення пошукової системи «Google» від словникової системи «Словники України онлайн».

Акцентуємо увагу на використанні електронних лінгвістичних ресурсів у закладі загальної середньої освіти й аналізуємо вправи підручника «Українська мова» для учнів 10-класу за ред. М. Плющ (Плющ та ін., 2010, с. 246). Наприклад: На сайті wwu.mova.info ознайомтеся зі структурою електронних словників. Чи легко ними користуватися? Які труднощі у вас виникали? Тому привертаємо увагу студентів до проблемно-пошукових завдань з використанням електронних словників.

Апробовуємо також низку вправ із метою організації навчальнодослідницької роботи школярів МАН із використанням українського національного лінгвістичного корпусу: творчі вправи: створити рекламну листівку до електронного словника; відеоролик із демонстрацією можливостей електронного словника; розмістити в соціальній мережі та зібрати «лайки»; провести конкурс на краще інтерв'ю «Що Вам відомо про сучасні словники? Якими Ви уявляєте словники майбутнього?»; укласти електронний словничок лінгвістичних термінів із теми «Лексикологія», використовуючи новітні інформаційні технології (наприклад, метод «слайдшоу»); створити відеословник «Топоніми навколо Вас»; порівняй частотність уживання та значення лексеми «освіта» у творах Тараса Шевченка, Олеся Гончара, Ліни Костенко (використай Національний лінгвістичний корпус).

Результатом успішної роботи $\epsilon$ зацікавлена участь студентів у підготовці збірника вправ із використання електронних ресурсів Українського мовно-інформаційного фонду НАН України для учнів 10 класу, проєкт студентів із українського правопису під час міжнародної науковопрактичної конференції здобувачів «Академічна культура дослідника в освітньому просторі: європейський та національний досвід» (2020).

Упродовж 2020 р. закладами спільно проведено Свято українського словника в Міжнародний день рідної мови (лютий 2020 р.), усеукраїнську науково-практичну конференцію «Інновації в освіті і педагогічна майстерність вчителя-словесника (листопад 2020 р., круглий стіл «Мова медіа і словники», лютий 2020 р.); міждисциплінарні заняття «Використання корпусних технологій у роботі вчителя словесника» (квітень 2020 р.), вебінар «Плагіат, фейк та дезінформація: за лаштунками мовно-інформаційних технологій» (6.11.20). 
Зокрема, аналіз відповідей учасників спільного вебінару «Словникова майстерня» засвідчують: використання здобутків корпусної лексикографії стимулюють формування словникової культури особистості через гнучкість використання, оперативність обробки інформації, модульність побудови, сприяють оновленню й оптимізації навчально-пізнавальної діяльності за максимально короткий проміжок часу. Зокрема, А. Старченко, студентка Сумського державного педагогічного університету імені А. С. Макаренка, зазначає в есе, що «словники - це елемент національної культури; відбулася діджиталізація (оцифровування словників); існування комп'ютерного словникарства й паперового має інтегруватися».

Висновки та перспективи подальших наукових розвідок. Отже, аналіз наукових джерел дає підстави розглядати словникову культуру як важливий індикатор академічної культури й академічної грамотності дослідників. Електронні словники надають користувачеві безліч додаткових можливостей порівняно з друкарськими аналогами: дозволяють зберігати великий обсяг інформації за рахунок використання гіперпокликань; мають ефективну систему пошуку (повнотекстовий або одночасний пошук у кількох словниках, швидкість пошуку); значно зекономлюють час і матеріальні ресурси під час створення комп'ютерних словників.

Серед сучасних лінгвістичних електронних ресурсів, які доцільно використовувати у процесі занять із дисциплін «Академічна культура педагога-дослідника», «Методика навчання української мови у старшій школі», вагоме місце має бути відведено електронним лінгвістичним ресурсам Українського мовно-інформаційного фонду НАН України, словниковим модулям словозміни, транскрипції, синонімії, антонімії та фразеології, лінгвістичному корпусу (понад 200 млн. слововживань) 3 розвиненими мовно-інформаційними функціями.

Аналіз досвіду бінарних занять, проведених спільно науководослідною лабораторією «Академічна культура дослідника» кафедри української мови і літератури Сумського державного педагогічного університету імені А. С. Макаренка та Загальноукраїнським центром словникарства Українського мовно-інформаційного фонду НАН України, засвідчує, за експертними оцінками здобувачів освітнього рівня магістр, ефективність апробованих проблемно-пошукових вправ, ключовими словами яких є дослідження, академічна доброчесність, європейський, новаторство, авторитет; творчих вправ, спільного проєкту «Словникова майстерня». Реалізація проєкту «Словникова майстерня», зокрема підготовка мультимедійного словника 3 медіаграмотності 
дозволить оптимізувати процес комунікативної взаємодії, академічну культуру суб'єктів освітнього процесу. Експериментальну перевірку дослідницьких пропозицій представимо в наступних публікаціях.

\section{ЛІТЕРАТУРА}

Гальченко, М. С., Надутенко, М. В., Широков, В. А., \& та ін. (2013). Збірник завдань з української мови з використанням електронних ресурсів корпусу МАН України. CITICחPIHT (Halchenko, M. S., Nadutenko, M. V., Shyrokov, VA, et al. (2013). Collection of tasks in the Ukrainian language using electronic resources of the corpus of the M inor Academy of Sciences of Ukraine. CITY SPRINT).

Довгий, С. О. та ін. (2013). Комп'ютерні онтології та їх використання у навчальному процесі. Теорія і практика. Інститут обдарованої дитини (Dovhyi, S. O. et al. (2013). Computer ontologies and their use in the educational process. Theory and practice. Gifted Child Institute).

Методичні рекомендації щодо розроблення стандартів вищої освіти. Режим доступу: https://law.chnu.edu.ua/metodychni-rekomendatsii-shchodo-rozroblenniastandartiv-vo/ (M ethodological recommendations for the development of standards of higher education. Retrieved from: https://law.chnu.edu.ua/metodychnirekomendatsii-shchodo-rozroblennia-standartiv-vo/).

Надутенко, М.В. (2020). Загальний огляд та перспективи використання національних лінгвістичних цифрових ресурсів Українського мовно-інформаційного фонду НАН України. Проблеми загального та порівняльно-історичного мовознавства, (сc. 91-95). НаУКМА. Режим доступу: http://ekmair.ukma.edu.ua/handle/123456789/17607?show full (Nadutenko, M. V. (2020). General overview and prospects of using national linguistic digital resources of the Ukrainian Language and Information Fund of the National Academy of Sciences of Ukraine. Problems of general and comparative-historical linguistics, (pp. 91-95). NaUKMA. Retrieved from: http://ekmair.ukma.edu.ua/handle/123456789/17607?show full).

Організація навчально-дослідницької роботи школярів із використанням українського національного лінгвістичного корпусу. МАН. Режим доступу: http://man.gov.ua/files/49/ORHANIZATsIYA.pdf (Organization of educational and research work of schoolchildren with the use of the Ukrainian national linguistic corpus. MAS. Retrieved from: http://man.gov.ua/files/49/ORHANIZATsIYA.pdf).

Плющ, М., Тихоша, В., Караман, С. (2010). Українська мова: підручник для 10 кл. загальноосвіт. навч. закл. з навч. укр. мовою : профріл. рівень. Освіта (Plushch, M., Tykhosha, V., \& Karaman, S. (2010). Ukrainian language: textbook for 10 classes, general education: profile level. Education).

Про використання електронних освітніх ресурсів, Наказ МОН, молоді та спорту України № 1060 (2012). Режим доступу:

http://zakon4.rada.gov.ua/laws/show/z1695-12 (On the use of electronic educational resources, Order of the Ministry of Education and Science, Youth and Sports of Ukraine № 1060 (2012). Retrieved from: http://zakon4.rada.gov.ua/laws/show/z1695-12).

Про освіту, Закон України №2145-VIII (2020). Режим доступу: https://zakon.rada.gov.ua/laws/show/2145-19. (On education, Law of Ukraine (2020). Retrieved from: https://zakon.rada.gov.ua/laws/show/2145-19).

Про вищу освіту, Закон України № 2145-VIII (2020). Режим доступу: https://zakon.rada.gov.ua/laws/show/1556-18/page\#Text (On higher 
Педагогічні науки: теорія, історія, інноваційні технології, 2020, № 10 (104)

education, Law of Ukraine (2020). Retrieved from: https://zakon.rada.gov.ua/laws/show/1556-18/page\#Text).

Семеног, О. М. (2020). Концепт «академічна культура дослідника» в українському і польському освітньо-педагогічному дискурсі. Український Щорічник $з$ Європейських Інтеграційних Cтудій, (сс. 139-152). APREI (Semenog, O. М. (2020). The concept of "academic culture of the researcher" in the Ukrainian and Polish educational and pedagogical discourse. The Ukrainian Yearbook of European Integration Studies, (pp. 139-152). APREI).

Семеног, О. М. (2019). Концептосфера освіта в українському та польському дискурсах: міждисциплінарний підхід. СумДПУ імені А. С. Макаренка (Semenog, О. М. (2019). The conceptual sphere of education in Ukrainian and Polish discourses: an interdisciplinary approach. Sumy State Pedagogical University named after A. S. Makarenko).

Семеног, О., \& Вовк, М. (2016). Академічна культура дослідника в освітньо-культурному просторі університету. СумДПУ імені А. С. Макаренка (Semenog, 0., \& Vovk, M. (2016). Academic culture of the researcher in the educational and cultural space of the university. Sumy State Pedagogical University named after A. S. M akarenko).

Широков, В. (2003). Всеукраїнський лінгвістичний діалог у контексті теорії лексикографічних систем. Мовознавство, (6), 3-7 (Shyrokov, V. (2003). AllUkrainian linguistic dialogue in the context of the theory of lexicographic systems. Linguistics, (6), 3-7).

Широков, В.А. та ін. (2018). Лінгвістично-інформаційні студії: праці Українського мовно-інформаційного фонду НАН України. Український мовно-інформаційний фонд НАН України (Shyrokov, V. A. et al. (2018). Linguistic and information studies: works of the Ukrainian language and information fund of the National Academy of Sciences of Ukraine. Ukrainian Language and Information Fund of the National Academy of Sciences of Ukraine).

Широков, В. (2017, 14 липня). Ми маємо унікальний інструмент, якого немає в світі. Дзеркало тижня. Режим доступу: https://zn.ua/ukr/science/volodimir-shirokovmi-mayemo-unikalniy-instrument-yakogo-nemaye-v-sviti-248438 .html (Shirokov, V. (2017, July 14). We have a unique tool that does not exist in the world. Mirror of the week. Retrieved from: https://zn.ua/ukr/science/volodimir-shirokov-mi-mayemounikalniy-instrument-yakogo-nemaye-v-sviti-248438 html).

Semenog, O. M. (2020). Academic culture as a composition of national innovation security. UNESCO Chair Journal "Lifelong Professional Education in the XXI Century", (2), 48-53. Retrieved from: https:// doi.org/10.35387/ ucj.2(2).2020.48-53.

Schleicher, A. (2019). PISA 2018 Insights and Interpretations 2018. OECD. Retrieved from: https://search.oecd.org/pisa/PISA 2018 Insights and Interpretations FINAL PDF.pdf.

\section{PEЗЮME}

Семеног Елена, Надутенко Маргарита, Тимощук Роман. Национальные лингвистические ресурсы Украинского языково-информационного фонда НАН Украины эффективное средство формирования академической культуры исследователя.

В статье сделан обзор национальных лингвистических ресурсов Украинского языково-информационного фонда НАН Украины как эфрективного средства в подготовке будущих учителей-словесников к формированию академической культуры (терминологической, лексикографической) ученика-исследователя. Доказано, что электронные национальные лингвистические ресурсы характеризуются гибкостью, оперативностью обработки информации, модульности построения, способствуют обновлению и оптимизации учебно- 
познавательной деятельности за максимально короткий промежуток времени. Освещены отдельные результаты междисциплинарного проекта Всеукраинского центра словарного Украинского языково-информационного фонда НАН Украины и каредры украинского языка и литературы Сумского государственного педагогического университета имени А. С. Макаренко.

Ключевые слова: академическая культура, исследователь, иифровые ресурсы, электронный словарь, национальная словарная база, Всеукраинский центр словарного Украинского языково-информационного фонда НАН Украины, кафедра украинского языка и литературы, междисциплинарный проект.

\section{SUMMARY}

Semenog Olena, Nadutenko Marharyta, Tymoshuk Roman. National Linguistic Resources of Ukrainian Lingua-Information Fund of NAS of Ukraine are an effective tools for forming-up the academic culture of the researcher.

The article reviews the national linguistic resources of the Ukrainian LinguaInformation Fund of the National Academy of Sciences of Ukraine, their use in the training of future philologists in the formation of academic culture (terminological, lexicographical) of student youth. It is proved that electronic national linguistic resources are characterized by flexibility, efficiency of information processing, modularity of construction. These resources contribute to the renewal and optimization of educational and cognitive activities in the shortest possible time.

Among modern linguistic electronic resources that should be used in the disciplines of "Academic culture of a teacher-researcher", "M ethods of teaching Ukrainian in high school", an important place should be given to electronic linguistic resources of the Ukrainian Language and Information Fund of NAS of Ukraine, dictionary modules word change, transcription, synonymy, antonymy and phraseology, linguistic corpus with developed linguistic and informational functions. The National Linguistic Corps is a modern experimental basis for conducting basic linguistic research and compiling lexicographical works of the new generation.

Article highlights some results of the interdisciplinary project of the All-Ukrainian Dictionary Center of the Ukrainian Lingua-Information Fund of the National Academy of Sciences of Ukraine and the Department of Ukrainian Language and Literature of Sumy State Pedagogical University named after A.S. M akarenko.

Analysis of the experience of binary classes conducted jointly testifies to the effectiveness of problem-solving exercises, the key words of which are research, academic integrity, European, innovation, authority; joint project "Dictionary Workshop", which implementation will optimize the process of communicative interaction, academic culture of the subjects of the educational process.

Key words academic culture, researcher, digital resources, electronic dictionary, national dictionary database, All-Ukrainian Center for Vocabulary of the Ukrainian Language and Information Fund of the National Academy of Sciences of Ukraine, Department of Ukrainian Language and Literature, interdisciplinary project. 